Nigerian Journal of Physiological Sciences 24 (2): 157 -159 @Physiological Society of Nigeria, 2009

Available online/abstracted at http://www.bioline.org.br/np; www.ajol.info/journals.njps; www.cas.org

\title{
MEDICINAL PROPERTIES OF FRACTIONATED ACETONE/WATER NEEM (AZADIRACHTA INDICA) LEAF EXTRACT FROM NIGERIA: A REVIEW
}

\section{UGOCHUKWU B. ANYAEHIE}

Department of Physiology, College of Medicine, University of Nigeria, Enugu Campus; Enugu, Nigeria Email:ugobond@yahoo.com

Summary: The global scenario is now supporting the development of modern drugs from less toxic plant products with proven medicinal properties. Each part of neem plant (Azadirachta indica A. Juss) reportedly has various medicinal properties and has been in use in many continents for centuries. Recently, a fractionated neem-leaf extract known as IRAB with reported activities against Malaria, HIV/AIDS and cancer has been developed into a drug and currently marketed in Nigeria as IRACAP®. This paper reviews the medicinal properties, clinical studies and safety concerns of this fractionated acetone-water neem leaves extract as a footstep to further studies both on the extract and/or its chemical constituents.

Key words: IRAB, dogonyaro, Malaria, Nigeria

\section{Introduction}

Extracts from neem tree (Azadirachta indica A. Juss) also called "dogonyaro" in Nigeria are most consistently recommended in ancient medical texts for gastrointestinal upsets, diarrhea and intestinal infections, skin ulcers and infections, and malaria (Schmutterer,1995). India encouraged scientific investigations of neem tree as part of his program to revitalize Indian tradition and also increase commercial interest on neem (Stix, 1992) and presently some authors believe that no other plant or tree in the world has been so extensively researched or used, in all possible capacities so far. In Africa extracts from Neem leaves have provided various medicinal preparations (Ekanem, 1971 and Udeinya, 1993). A fractionated acetone-water extract also known as IRAB has been showing safer medicinal properties (Mbah et al, 2007). In-vitro studies with malaria-infected erythrocytes and metastatic cancer cells had earlier shown that IRAB has broadspectrum anti-cytoadhesion activity which has been beneficial in HIV/AIDS (Udeinya et al, 2004). Mbah et al (2007) reports IRAB as safe and able to increase CD4+ cell levels in HIV/AIDS patients.
Extraction, fractionation, Chemical components of Nigerian neem leaf extract (IRAB)

Fractionated neem leaves extract with registered U.S. Pat. No. 5,370,873 issued Dec. 6, 1994 (also known as IRAB) is registered and marketed in Nigeria in $250 \mathrm{mg}$ capsules as IRACARP® (NAFDAC Registration number A7-0319L). Extraction is done using neem leaves collected in Nigeria in a mixture of acetone and water $(1: 1$, by vol.) as described by Udeinya (1993). Residue from the bottom layer of the crude extracts is then fractionated by standard, high-performance liquid chromatography (HPLC) (Udeinya et al, 2006). The end product (IRAB) is a complex molecule (202 Daltons) with functional groups that include sodium salts of carboxylic acid and a non-aromatic dialcohol (Mbah et al, 2007).

Reported medicinal actions of IRAB:

In-vitro and in-vivo studies on IRAB have revealed the following activities: 
Anti-malaria:

Extracts from Nigerian neem leaves (Azadirachta indica) have been earlier reported to have anti-malarial activities (Ekanem, 1971), but Udeinya (1993) demonstrated that acetone/water mixture is a more efficient solvent than water alone for the extraction of anti-malarial activity from Nigerian neem leaves. This activity has been reportedly retained by IRAB (Udeinya et al 2006 and 2008). Its anti-malarial activity has been reported to be superior to chloroquine (Udeinya et al, 2006), gametocytocidal. (Udeinya et al, 2006 and 2008) and schizonticidal (Udeinya 2008) against faliciparium malaria parasite. Indeed Anyaehie (2009) reported anti-pyrexial activity among Nigerians where malaria remains the commonest cause of Fever. Patients from malaria are also likely to benefit from reported anticytoadhension property of IRAB since adhesion of infected erythrocytes to the endothelium is key factor in pathogenesis of severe falciparium malaria (David et al, 1983).

\section{Anti-retroviral:}

Udeinya et al (2004) first reported antiretroviral activity by IRAB on patients with HIV/AIDS in a phase I clinical trial. In another study by Mbah et al (2007) that lasted 12 weeks, IRAB was administered ( $1 \mathrm{~g}$ daily) to 60 patients infected with HIV-1 \& 11. The results showed a significant increase from the baseline mean $\mathrm{CD} 4^{+}$cell count of 266 cells/ul by week 12 . Mean body weight and hemoglobin concentration were also significantly increased. Opportunistic infections and other HIV/AIDS related conditions were reportedly completely resolved in most patients by week 12 . Also, the erythrocyte sedimentation rate (ESR) was reported to have been significantly decreased from a baseline mean value of $64 \mathrm{~mm} / \mathrm{hr}$ to $16 \mathrm{~mm} / \mathrm{hr}$.

Anyaehie (2009) compared the anti-retroviral properties of IRAB with that of highly active antiretroviral therapy (HAART) and results are consistent with Mbah et al (2007) after 16weeks of therapy. However, Anyaehie (2009) documented a more significant increase in CD4+ cells and elimination of skin rashes among patients on HAART compared to patients on IRAB. Mbah et al (2007) and Anyaehie (2009) agree that there was a significant improvement in patients' condition with respect to presenting symptoms and physical examination findings. These reports of correction of CD4+ cell counts and improvement in patients' clinical profile may indeed relate to corresponding reduction in viral activity and led to a presumptive conclusion that the fractionated neem leaf extract (IRAB) is safe and increases CD4+ Cell Levels in HIV/AIDS patients, a conclusion the work of Anyaehie (2008) further supported.

\section{Are there any side effects or interactions?}

Neem leaf extracts appear to be very safe at recommended intake levels with no significant reports of problems. Also, use of IRAB has consistently reported no adverse effects either as an anti-malaria (Udeinya et al, 2006 and 2008) or an anti-retroviral agent (Mbah et al, 2007 and Anyaehie 2009). Water extracts of neem leaf have been shown to decrease blood levels of chloroquine in rabbits (Nwafor et al, 2003) but this has not been investigated with IRAB. The use in pregnancy has also not been evaluated and thus is not yet recommended. At the time of writing, there were no well-known drug interactions with IRAB. 
Medicinal properties of Azadirachta indica: Review

\section{Conclusion}

Development of modern non-toxic drugs from neem has earlier been suggested (Biswas et al, 2002) and IRAB represents such dream. This fractionated acetone/water neem leaf extract is the only drug reported to have activities against Malaria and HIV/AIDS. Recent in-vivo studies have substantiated the earlier in-vitro reports of pharmacological properties. The drug is reportedly safe, and thus further studies both on the extract and/or its chemical constituents are highly suggested to streamline these innovative findings into strategies for achieving the health components of the Millennium Development Goals (MDGs).

\section{References}

Anyaehie, U. S. B. (2009). Changes in some Physiological parameters of HIV/AIDS patients on Anti-retroviral and neem (Azadirachta indica) extract in Enugu, Nigeria. Ph.D. thesis, Abia State University, Uturu, Nigeria.

Biswas, K., Chattopadhyay, I., Baerjee, R. K. and Bandyopadhyay, U. (2002). Biological activities and medicinal properties of neem (Azadirachta indica). Curr. Sci. 82(11): 1336-1345.

David, P. H., Hommel, M., Miller, L. H., Udeinya, I. J. and Oligino, L. D. (1983). Parasite sequestration in Plasmodium falciparum malaria: spleen and antibody modulation of cytoadherence of infected erythrocytes. Proc. Natl. Acad. Sci. USA. 80(16): 5075-5079.

Ekanem, O. J. (1971). Has Azadirachta indica (dogonyaro) any antimalarial activity? Niger. Med. J. 8: 8-11.

Mbah, A. U., Udeinya, I. J., Shu, E. N., Chijioke, C. P., Nubila, T., Udeinya, F., Muobuike, A., Mmuobieri, A. and Obioma, M. S. (2007).
Fractionated neem leaf extract is safe and increases $\mathrm{CD}^{+}$cell levels in HIV/AIDS patients. Am. J. Ther. 14(4): 369-374.

Nwafor, S. V., Akah, P. A., Okoli, C. O., Onyirioha, K. C. and Nwosu, C. S. (2003). Interaction between chloroquine sulphate and aqueous extract of Azadirachta indica A. Juss (Meliaceae) in rabbits. Acta Pharm. 53:305311.

Schmutterer, H. (1995). The Neem Tree. In: Schmutterrer, H., Ascher, K. R. S., Isman, M. B., eds. The Neem Tree: Azadirachta indica A Juss and other Meliaceous Plants. Weinheim, Germany, pp. $1-3$.

Stix, G. (1992). Village pharmacy: The neem tree yields products from pesticides to soap. Sci. Am. 266:132.

Udeinya, I. J. (1993). Anti- malarial activity of Nigerian neem leaves. Trans. Royal Soc. Trop. Med. Hyg. 87: 471.

Udeinya, I. J., Brown, N., Shu, E. N., Udeinya, F. I. and Quakeyie, F. (2006). Fractions of an antimalarial neem-leaf extract have activities superior to chloroquine and are gametocytocidal. Ann. Trop. Med. Parasitol. 100(1): 17-22.

Udeinya, I. J., Mbah, A, U., Chijioke, C. P. and Shu, E. N. (2004). An anti-malarial extract from neem leaves is antiretroviral. Trans. Royal Soc. Trop. Med. Hyg. 98:453-437.

Udeinya I. J., Shu, E. N., Quakeyie, F. and Ajayi, F. O. (2008). An antimalarial neem-leaf extract has both Schizonticidal and gametocytocidal activities. Am. J. Ther.15: 108-110.

Received: November 12, 2009 Accepted: December 28, 2009 